\title{
Præsten Johs. Kok og skolevæsenet i Burkal sogn
}

\section{Af Hans Vald. Gregersen.}

Blandt det kuld præster, der efter treårskrigen fik en gerning i det omstridte grænseland, var Johs. Kok, ${ }^{1}$ ) der den 8. maj 1851 blev valgt til sognepræst i Burkal, hvor han havde sit virke, indtil han den 29. april 1864 måtte vige for de nye magthavere.

Kirkeligt set var han nærmest konservativ; han var bl. a. påvirket af den myndige daværende professor i teologi, senere biskop H. L. Martensen og stod således den grundtvigske folkelighed fjernt. Men da han var en fremragende prædikant, samlede han gerne en stor tilhørerskare i sin kirke og blev meget afholdt som præst.

Politisk var han grebet af tanken om at vinde Sønderjylland for dansk åndsliv. Der skulle rådes bod på den sønderjydske befolknings vantrivsel gennem århundreder. Han følte sig som sine kaldsfæller udsendt af regeringen „for at stride for gamle Danmark". Og han ville ikke nøjes med at føre denne kamp fra prædikestolen.

Da han i sin ungdom havde virket et par år som adjunkt ved Århus katedralskole, undrer det ikke, at han straks efter sin an-

1) Johannes Georg Elias Koch, f. Ledreborg 1821 24. 2. som s $\not n$ af en tyskfødt slotsgartner, d. 1887 20. 1. som præst ved Citadelskirken i K $\phi-$ benhavn. Se iøvrigt Dansk biografisk Leksikon og Sønderjydsk månedsskrift 5. årg. 161-165. I løbet af 1862 gik han over til at lade sit navn skrive Joh. Kok. Da han er mest kendt med navnet stavet på den måde, er denne skrivning gennemført her for efternavnets vedkommende. 
komst til Burkal netop omfattede skoleforholdene i sit nye virkefelt med særlig interesse. Som sognepræst var man jo i de tider også tilsynsførende ved det stedlige skolevæsen, og der bod sig derfor en naturlig anledning til at varetage denne betydningsfulde sag med største omhu. Af sin tids sønderjydske præster blev Johs. Kok en af dem, der ydede mest til gavn for almueskolen og her var han ikke bange for at gore brug af de grundtvigske tanker.

Man kan vist rolig gå ud fra som givet, at Slogs herred omkring 1850 stod i yderste fare for at komme til at dele Kær herreds fremtidige nationale lod. Den velhavende og mest oplyste del af herredets befolkning var overvejende tyskpræget, og kun et aktivt oplysningsarbejde blandt sognenes politisk indifferente befolkning kunne afvende faren for fortyskning.

Om tilstanden i Burkal sogns skoler skriver Johs. Kok kort efter sin tiltrædelse ${ }^{2}$ ): "Imidlertid gjælder det om denne Skole, hvad der desuden gjælder om næsten alle Skoler her i Sognet og vel i hele Slesvig, at Børnene ere blevne forquaklede derved, at man har villet bibringe dem Kundskaber i Tydsken og derved frembragt en Tungemaalenes Forvirring næsten ligesom den, Jahve frembragte ved Babel for Folkets Synders Skyld. Man kan saaledes af denne tydske Protokol ikke ret see, om Skolerne hidtil have været danske eller tydske. Besynderligt er det, at fornuftige Folk have kunnet indbilde sig, at det med saa slet Skolebesøg, som her finde Sted, var muligt at lære Almuebørn to Sprog. Sagen har rimeligviis været den, at de hellere have villet, at Børnene Intet skulde lære, end læse Dansk dette patois, der skurrede saa fælt i deres tydskdannede Øren -. En ordentlig dansk Læsebog savnes saaledes i alle Skolerne et mærkeligt Savn i danske Skoler! - Børnene have afbenyttet deres Religionsbøger til Indenadslæsning - hvilket pædagogisk Misgreb! -

2) I. A. Burkal præstearkiv. Skolepratokol for Præsten 1845-62. (Burkal skole 6. 10. 1851); uddrag af denne protokol er tidligere bragt i Jydske Tidende 1948 22. 8. 
I Geographie er kun blevet underviist saare lidet, i Fædrelandshistorie intet - Tiden skulde naturligviis anvendes til Tydsk, som var mere vigtigt, og desuden havde jo Fædrelandet "S'lesvigholsteen“ endnu ingen Historie, den var jo mestendels kun et ufødt Foster i enkelte kielske Professorers Hjerner. Ret charakterisk for den Omhyggelighed, hvormed man søgte at skjule for Slesvigerne, at de vare danske, er det Svar, som en Præst gav en Skolelærer her i Sognet, da han bad ham om at faae et Danmarks Kort til Brug ved Geographie-Underviisningen: Det behøves ikke for Øjeblikket, thi om kort Tid faae vi en heel ny "Geographie«! For hans geographiske Blik har Phantasistaten "Slesvigholsteen " svævet; men nu har Tiden viist, at hans Propheti var falsk.

Tildels af ovennævnte Grund har Religion været næsten det eneste Fag i Skoleunderviisningen - et stort Misgreb, thi for at blive Borger $\mathrm{i}$ Guds Rige er Troen paa Christus visselig det ene Fornodne, men for at være en god og tro Borger $i$ et jordisk Rige behøves Mere, behøves navnlig Kundskab til Fædrelandets Historie i Nutid som i Fortid, Kjerlighed til Fædrene og deres store Bedrifter. Havde man ikke forsætlig skjult disse for Slesvigerne og planmæssigt løsrevet dem fra Minderne om Danmarks Storhed og Glands i de henfarne Dage, saa skulde aldrig taabelige Løgne have formaaet dem til at vende deres Vaaben imod det Land, af hvilket de med Stolthed burde have kaldt sig Sønner. Her rinder mig et Sandheds Ord af Grundtvig i Hu: „Fædreland har kun det Folk, som kjærligt mindes Forfædrene og tilegner sig deres Modersmaal“. (Krønike Riim S. 256). Gud lad det dog skee, at Slesvigs umyndige Sønner og Døttre, hvis Forældre have glemt Forfædrene og tildels ogsaa deres Modersmaal, maae atter vinde Kjerlighed til det, uden hvilket et Folk tilsidst sløvt synker hen i Afmagt! Da - men ogsaa først da skal det skee, at et kraftigt Liv i Christus, vor Frelser, skal vaagne trindtomkring, og Sandheden i ham skal frigjøre dem fra Løgnens Lænker! I Haab herom - Gud lade mit Haab ikke be- 
skæmmes! — vil jeg arbejde; Herren give mig mange Medarbejdere med samme Villie og bedre Kræfter!“

Den skarpe fordømmelse af de hidtidige ledere af skolevæsenet skal bedømmes ud fra hans nationalliberale indstilling, men kernen i problemet: vækkelse af den slumrende danskhed skal foregå som Grundtvig ønskede det: ved indførelse i dansk åndsliv. Mangelen på ordentlige skolebøger og en fornuftig undervisningsplan anså han for de værste ulemper, der derfor omgående måtte bringes $\mathrm{i}$ orden. Ved hensigtsmæssig benyttelse regnede han Hjorts „Børneven“ for så „nyttig, at den ikke burde savnes i nogen Almueskole“. Den var dog ikke hidtil indført i ret mange skoler i Tønder provsti og modte også en del modstand hos landbefolkningen. Foruden visen om den tapre landsoldat, som ikke var efter de slesvigholstensksindedes smag, var nemlig bøndernes påholdenhed den store hindring for anskaffelsen af nye lærebøger. Burkal-præsten så sig derfor nødsaget til $i$ et brev til departementschef Regenburg i det slesvigske ministerium at anmode denne om bistand ved anskaffelsen af en snes eksemplarer til brug for fattige børn. Det var nemlig hans håb at få den indført $i$ alle sognets skoler i løbet af vinteren 1851-52.

For øvrigt fik Johs. Kok meget hurtigt øjnene op for, at hjemmetyskheden ikke uden videre lod sig borteliminere. Først under og efter treårskrigen havde de nye nationalitetsideer vundet indpas hos en del af Burkal sogns indvånere. Det var derfor her som i så mange andre sogne den nyansatte danske præsts fornemste mission at hidføre en national dansk vækkelse. Hertil krævedes forst og fremmest takt og tålmod. Johs. Kok kunne snart meddele, at menighedens stemning bestandig blev bedre, men der fandtes dog stadig nogle ,forvopne Tydskere, som bestandig saae Klinte blandt Hveden; af Saadanne maa man opgive Haabet om at kunne giøre Proselytter og indskrænke sig til at giøre dem saa uskadelig som muligt, hvilket ikke er let, da de

3) RA. Regenburgs arkiv. Kok til R. 1851 19. 12. 
kun arbejde i Stilhed og altsaa kun indirecte kunne modarbejdes". I nationalpolitiske spørgsmål hyldede han derfor — som han selv skriver - valgsproget: „Festina lente“ (o: il langsomt $=$ hastværk er lastværk). Den nationale kamp om Sønderjyllands befolkning ville blive en sejg kamp på det kulturelle område. Til en sådan kamp om sjælene krævedes bl. a. også oprettelsen af et sognebibliotek, hvortil han modtog betydelige bidrag fra Århus og København. Derved så han sig i stand til at fastsætte et meget lavt kontingent for bibliotekets lånere. ${ }^{3}$ )

Med hensyn til indførelsen af nye gode lærebøger i skolerne nåede han hurtigt meget vidt, takket være et energisk arbejde for denne sag. Inden hans første vinter i Burkal var omme, lykkedes det ham at indføre Balslevs katekisme og bibelhistorie i de fleste af sognets skoler. Dette skridt mødte imidlertid heller ikke den mindste modstand fra forældrenes side, fordi han ved en betydelig gave fra Århus var sat $i$ stand til at overlade fattige og mindrebemidlede børn bøgerne gratis eller til halv pris. Derimod satte den tysksindede provst Ahlmann i Tønder sig imod indførelsen af de nye bøger. ${ }^{4}$ ) ,Havde vi kun nogen Bistand og ikke idelig Modstand, hemmelig eller aabenbar fra dette højere Sted, da kunde denne Deel af Slesvig frelses, men saalænge der undervises af tydskdannede Lærere, efter halvtydske Lærebøger, under Inspection af tildeels tydsksindede Præster og Overtilsyn af den nuværende Provst, saalænge maa nodvendigviis status quo ante vedvare o: Tydskheden gribe om sig. Hans Overopsyn er imidlertid meest farlig, og hans Indflydelse meest skadelig i de halvtydske Distrikter, hvor dansk Sprog skal ind-

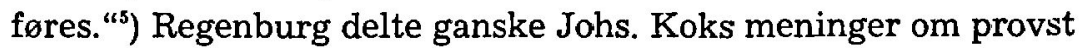
Ahlmann. I et brev til Krieger udtalte han således, at Ahlmanns forbliven i sit embede egentlig stred mod al offentlig moral.")

4) RA. Regenburgs arkiv. Kok til R. 1852 17. 2.

5) RA. Regenburgs arkiv. Kok til R. 1851 19. 12.

•) Smstds. R. til Krieger 1851 20. 11. Smlgn. H. Hjelholt: Den danske Sprogordning og det danske Sprogstyre i Slesvig mellem Krigene 1850 -1864 (1923) s. 34. 
Nogle måneder senere - i 1852 - blev provsten derfor pensioneret, og en hindring for Johs. Koks arbejde var dermed fjernet.

Trods alt kronedes hans arbejde for at ophjælpe undervisningen i Burkal sogn med held. Allerede efter første vinter kunne han fremvise et godt resultat: „Børnenes Fremgang har været bedre, end man skulde vente, naar een Lærer skal undervise circa 80 Børn i en Alder fra 6 til 16 Aar med højst forskjellige Evner. ${ }^{\text {"7) }}$ )

Det store børnetal var en frygtelig hemsko, som imidlertid ikke let lod sig afvende. Men også undervisningsplanen var uheldig. Som præst så han meget fordomsfrit på dette spørgsmål. Han var klar over, at der måtte foretages en ændring med hensyn til faget religions stilling i skolen, idet det lagde alt for stort beslag på timeplanen. Han skriver herom: „Læreren synes at anvende sin meste Flid paa Religionsunderviisningen ikke uden Skade for de øvrige Fag. Maatte jeg raade, da skulde Underviisningen i dette Fag indskrænkes til Bibelhistorie og Luthers lille Catechismus, og Børnene indhente det Manglende ved at gaae 2 Aar til Præsten; det var efter min Mening den bedste Maade, hvorpaa Præsten kunde komme Skolen til Hjælp. Hvad nytter desuden al den megen Catechisation og Catechismusudenadslæren? Er Læreren ingen christelig Mand, da skader den, idet han lettelig kommer, med eller mod sin Villie, til at bibringe Børnene falske Lærdomme; er han derimod en christelig Mand, da vil han let kunne uddrage alle Lærdomme af Bibelhistorien i Forening med det nye Testamente, som naturligvis altid bør være ved Haanden under Religionsunderviisningen, saa at Børnene tidlig kunne blive fortrolige med Brugen af den. ${ }^{(77}$ )

Tanken om den sønderjydske landbefolknings kulturelle højnelse lå Johs. Kok stærkt på sinde lige fra den dag, han tiltrådte. Han forstod hurtigt, at dette ikke lod sig realisere udelukkende

7) Skoleprotokollen (Burkal skole 1952 26. 8.). 
ud fra almueskolen. Ligesom Grundtvig onskede han en fortsættelsesskole for ungdommen, dog ikke i lighed med den grundtvigske folkehøjskole, der for øvrigt i disse år endnu ikke havde haft megen sukces, men derimod en ungdomsskole med praktiske fag. „Hvad vi mangle, men maa arbejde paa at faa, er nogle dygtige danske Folk, som have lært lidt mere end almindeligt og derved kunne give Tonen an blandt deres Standsfæller. Deri have de Tydsksindede hidtil havt deres Styrke".') Disse ord blev først nedskrevet $\mathrm{i}$ krigsåret 1864, men allerede $\mathrm{i}$ sit andet virkeår i Burkal pønsede han på en plan, som dog først efter genforeningen kunne føres ud $i$ livet med oprettelsen af bl. a. efterskolen $i$ Rens. Han skriver herom til Regenburg: „Hostrup Præsten er som bekjendt gammel, daarlig som Prædikant, ringere som Sjælesørger og tydsk af Sindelag. Degnen, der er over 70 Aar gammel, har et af de bedste Embeder i Slesvig, idet han foruden et Degnekalds sædvanlige Emolumenter har en heel Plovs Land; han er ikke som Degnene i Almindelighed Skolelærer tillige, og har derfor i tidligere Aar anvendt sit Otium til at holde en tydsk privat Skole, der havde stærk Freqvents fra Omegnen. Skolelæreren er ogsaa ældgammel, hvorfor Provsten nu har beskikket ham til Hjælpelærer en Mand, der tidligere har fungeret i samme Egenskab i mit Sogn, men som jeg fandt aldeles ubrugelig, da han aldrig havde lært Noget. Det retteste vilde vist være, at baade Degnen og Skolelæreren gik af; der kunde da maaske af begge Embeders Indtægter oprettes en udvidet Bondeskole, hvortil der er stor Trang her i Egnen, idet nu mange Forældre, som have Lyst og Evne til, at deres Børn skulde lære lidt mere end det Almindelige, sende dem til andre Steder, hvor der ere dygtige Lærere, for at gaae i Skole et Par Aar - det Uheldige skeer da som oftest, at de gaaer over Grændsen og vende tilbage som halve eller hele Tydskere.")

8) RA. Regenburgs arkiv. Kck til R. 1864 8. 1.

') RA. Regenburgs arkiv. Kok til R. 1852 7. 11. 
Hoptrup-præsten, Chr. Hansen Hoeck, lod sig dog ikke pensionere før 1856, så Johs. Kok har måttet give afkald på denne plan, der på en praktisk måde havde kunnet skaffe de nødvendige midler til driften af en sådan skole, men det har åbenbart ikke kunnet lade sig gøre at føre den ud i livet, siden man ikke senere finder den fremsat. Regenburgs vedvarende mistro til de grundtvigske højskoler har vel været den vægtigste årsag. Det var imidlertid Koks stadige sorg, at de fremmeligste af sognets unge ofte fik videreuddannelse på tysksprogede skoler. Kostskolen i Christiansfeld havde således i disse år en del tilgang fra Burkal sogn, hvor pietistisk-herrnhutisk indstilling fra gammel tid havde vundet hævd hos befolkningen. ${ }^{10}$ ) En strid herom opstod forøvrigt i 1855, da han nægtede at give sit samtykke til, at et af hans sognebørn, en gårdmandsdatter, der havde gået $\mathbf{i}$ dansk skole, skulle konfirmeres på tysk i Christiansfeld. ${ }^{11}$ )

Et par år efter sin tiltrædelse i Burkal havde Johs. Kok fået sat nogenlunde skik på sognets skolevæsen. Nye og bedre lærebøger havde overalt vundet indpas, således foruden de allerede nævnte Børresens abc og læsebog, Grünfelds regnebog samt "kortfattede ledetråde" i historie og geografi; dertil kom nye landkort over Palæstina, Danmark og Europa, som han fandt blev anvendt med held $\mathrm{i}$ alle sognets skoler. "De nye Læreboger have overalt bidraget meget til at indføre en mere dansk Aand i Undervisningen, thi de gamle Lærebøger vare dog, om end affattede paa Dansk, fra Begyndelsen til Enden tydske.“12) Kun er det omme og vanskelige punkt stadig det alt for store børnetal, som var overladt den enkelte lærer. Endelig var det så som så med skolebesøget. I foråret 1854 mener han herom:

10) Smign. Sdj. Årbøger 1944, s. 97-129.

11)RA. Regenburgs arkiv. Kok til R. 1855 8. 2.; Friedrich Petersen: Der gegenwärtige Zustand der Kirche und Schule des Herzogthums Schleswig (Frankfurt am Main 1857) s. 41; J. Koch: Bidrag til Bedømmelsen af den kirkelige Tilstand i Nordslesvig før og nu (1858) s. 15.

12) Skoleprotokollen: Burkal skole 1855 24. 4. 
"Skolebesøget synes her som i de andre Skoler at blive noget bedre om Vinteren, dog er det langtfra godt. ${ }^{15}$ ) Året efter var det hans ønske, at hvert barn skulle bringes til at besøge skolen $i$ det mindste en hel dag ugentlig sommeren igennem, „saa skulde de med Guds Hjælp gjøre raske Fremskridt.“12)

I begyndelsen af 1855 håbede Johs. Kok på at kunne forlade sin hidtidige gerning i det mellemslesvigske hedesogn. Gl. Haderslev var opslået ledig. Over for Regenburg udtrykte han sit håb om dette kald i følgende vendinger: „I Burkal har jeg nu udrettet det Meste af, hvad der staaer i min Magt. Skolevæsenet, som ved min Ankomst var meget slet, staaer nu paa en meget respectabel Fod. Menigheden kommer i talrig Mængde i Kirke, og jeg har der stadigt Besøg fra Nabosognene. Dette synes tilvisse at være Alt, hvad jeg kan forlange, men det har altid været min Attraa at blive Kjøbstadpræst, og jeg troer desuden, at jeg i en Kjøbstad vilde kunne gavne den danske Sag, som ogsaa jeg efter bedste Evne begjærer at tjene, langt mere end paa Landet. Hvor højligt trænger ikke Skolevæsenet i Kjøbstæderne til Forbedring og flittigt Tilsyn!"14) Johs. Kok har altså selv anset sit virke for skolevæsenets højnelse som sit fornemste bidrag til arbejdet på Sønderjyllands kulturelle tilknytning til moderlandet.

Men omkring 1855 var det værste pionerarbejde gjort i Burkal sogn. Ved flere af sognets skoler virkede gode lærerkræfter, i hvis varetægt Johs. Kok trygt kunne overlade børnene og undervisningen. Blandt dem bør især fremhæves lærer og gårdejer Andreas Jakobsgård, som underviste i Lund skole med så megen varme - især i fædrelandshistorien -, at denne skole på hans tid blev anset for den bedste i en vid omkreds. Efter sin bortrejse fra Burkal i 1864 udtrykte Johs. Kok over for Regenburg ønsket om, at denne dygtige lærer måtte blive udnævnt

13) Smstds.: Burkal skole 1854 10. 4.

14) RA. Regenburgs arkiv. Kok til R. 1855 8. 2. 
til dannebrogsmand, da han havde bidraget væsentligt til, at beboerne i hans skoledistrikt for den allerstørste del var ivrigt dansksindede. ${ }^{15}$ )

Imidlertid fik Johs. Kok ikke sit ønske om forflyttelse opfyldt i 1855. Det blev Søren Kierkegaards åndsfælle H. P. Kofoed-Hansen, der fik Gl. Haderslev. Muligvis har Johs. Kok ved denne lejlighed følt sig forbigået; i så fald kunne det synes som om tilsidesættelsen har virket som en "udfordring" $i$ Toynbee'sk forstand. Fra nu af forstod han nemlig at skaffe respekt om sit navn ved at kaste sig ud i studier over det sønderjydske folkemål. I de kommende år skildrede han således „Den mellemslesvigske Slette og dens Beboere", ligesom han efterhånden fik samlet ikke færre end 2000 sønderjydske ordsprog og talemåder. Hans omfattende folkemålsstudier satte sig dog den skønneste frugt i tobindsværket „Det danske Folkesprog i Sønderjylland“, som han imidlertid ikke nåede at få fuldført i sin Burkal-tid. Selv om dette værk i dag kun har ringe betydning med hensyn til den etymologiske behandling, er gengivelsen af folkesproget og samlingen af person- og stednavne stadig af stor interesse. Som forfatter af disse folkemålsundersøgelser er han blevet kendt $i$ en videre kreds, mens hans indsats til fremme af skolevæsenet ikke hidtil er blevet påskønnet.

H ans Vald. Gregersen.

15) Smstds. Kok til R. 1864 31. 12.; Skoleprotokollen: Lund skole 1856 1. 9. 